\title{
Correlation between the electrical conductivity of honey in humid and in dry matter
}

\author{
MT Sancho, S Muniategui, JF Huidobro *, J Simal \\ Facultad de Farmacia, Departamento de Química Analítica, Nutrición y Bromatología, \\ Area de Nutrición y Bromatología, 15706 Santiago de Compostela (La Coruña), Spain
}

(Received 12 September 1990; accepted 14 March 1991)

\begin{abstract}
Summary - For 115 honeys, comparing electrical conductivities at $20^{\circ} \mathrm{C}$ in solutions containing $10.00 \mathrm{~g}$ of honey dissolved in $75 \mathrm{ml}$ of water $(x)$, used to determine $\mathrm{pH}$ and acidity type, and solutions containing $20 \%$ dry matter $(y)$ revealed a linear relation represented by $y=1.50 \times(r=0.9998)$. On this basis, solution electrical conductivity, $\mathrm{pH}$ and acidity type can be measured without data on honey moisture content.
\end{abstract}

honey / electrical conductivity / water content

\section{INTRODUCTION}

Electrical conductivity measurements of honey give an indication regarding its origin (floral or honeydew) and the source of nectar, and can detect whether bees have been artificially fed with sugar (Vorwohl, $1964 a, b)$. It has also been proposed as a measure of the suitability of the honey as a winter feed for bees (Kaart, 1961). Electrical conductivity is related to the content of mineral salts, organic acids, proteins and polyols of the honey (Crane, 1975).

Stitz and Szigvárt (1931) measured the electrical conductivity of various honey solutions at $50 \%$ dry matter and $20.5^{\circ} \mathrm{C}$ and observed variations of this parameter with temperature and concentration, finding maximum electrical conductivity values with $30-35 \%$ dry matter. Vorwohl (1964a, b), however, obtained maximum electrical conductivity values with solutions of $20-25 \%$ dry matter and proposed taking measurements with solutions of $20 \%$ dry matter. The measurement of the electrical conductivity of honey at this concentration has now become standard in many countries (Codex Alimentarius Commission, 1969), including Spain (Boletin Oficial del Estado, 1986).

A possible relation between the electrical conductivity of honey solution containing $10.00 \mathrm{~g}$ dissolved in $75 \mathrm{ml}$ of water, used to determine $\mathrm{pH}$ and acidity type (White, 1962; Association of Official Analytical Chemists, 31.168, 1984), and that of a solution containing $20 \%$ dry matter (Vorwohl, 1964a, b) was investigated to simplify the determination of all these parameters by taking measurements in one solution.

* Correspondence and reprints 


\section{MATERIALS AND METHODS}

The sample comprised 115 honeys from the Basque Country (a region in the north of Spain). To check the methiod, 10 additional honeys with moisture content $>20 \%$ from Galicia (a region in the north-west of Spain) and 9 honeys from the first sample, supercharged until they contained $25 \%$ moisture, were analysed.

Moisture content was determined by vacuum drying (White, 1969; Association of Official Analytical Chemists, 1984) with a vacuum oven and high vacuum pump.

A conductimeter was used with a $1.0 \mathrm{~cm}$ electrode (Radiometer Copenhagen Type CDM 2e No 187049 and Type CDC 104, respectively). Measurements were taken at $20^{\circ} \mathrm{C} \pm$ $0.1^{\circ} \mathrm{C}$.

The conductimeter was calibrated at $20^{\circ} \mathrm{C}$ with a potassium chloride solution having an electrical conductivity which did not differ by more than $5.0 \times 10^{-4} \mathrm{~S} \mathrm{~cm}^{-1}$ from that expected for honey using a standard method (Boletin Oficial del Estado, 1986).

Honeys were dissolved in water, and two solutions were prepared:

\section{Solution " $x$ "}

Ten g of honey exactly (humid matter) were dissolved in $75 \mathrm{ml}$ of distilled water following the procedure of White (1962) for measuring $\mathrm{pH}$ and acidity type.

\section{Solution " $\mathrm{y}$ "}

Honey solutions containing $20 \%$ dry matter were prepared by dissolving $10.00 \mathrm{~g}$ in up to $50 \mathrm{ml}$ of water (Vorwohl, 1964a, b).

In the 2 series of solutions ( " $x$ " and " $y$ "), satisfactory coefficients of variation $10.86 \%$ for solution " $x$ " and $0.57 \%$ for solution " $y$ ") were obtained from measurements of the electrical conductivity of 10 solutions of the same honey sample.

\section{RESULTS AND DISCUSSION}

Plotting the pairs of electrical conductivity measurements of solutions " $x$ " and " $y$ " for each sample gives (table I) a straight line that corresponds to the equation $y=1.50 x$ $(r=0.9998$ ) (fig 1). The high level of correlation is surprising; 2 honeys with the same content of conducting substances but different moisture contents should have identical electrical conductivity values for the humid matter but different values for the dry matter, since different quantities of honey must be weighed and dissolved to prepare solutions of $20 \%$ dry matter. The explanation lies in considering the joint effects of 2 properties, ie effect of moisture content and effect of concentration.

Table I. Electrical conductivity $\left(10^{-4} \mathrm{~S} \mathrm{~cm}^{-1}\right)$ in solution of wet matter " $x$ ", moisture content $(\% \mathrm{w} / \mathrm{w})$, weight of $10.0 \mathrm{~g}$ of dry matter (DM) and electrical conductivity $\left(10^{-4} \mathrm{~S} \mathrm{~cm}^{-1}\right)$ in solution of dry matter " $y$ " for the 115 honeys analysed from the Basque Country (Spain).

\begin{tabular}{llccc}
\hline & $\begin{array}{c}\text { Electrical } \\
\text { conductivity (“ }\end{array}$ & $\begin{array}{c}\text { Moisture } \\
\text { content (\%) }\end{array}$ & $\begin{array}{c}10 \mathrm{~g} \text { honey } \\
(D M)\end{array}$ & $\begin{array}{c}\text { Electrical } \\
\left.\text { conductivity (" }{ }^{\prime \prime}\right)\end{array}$ \\
\hline $\bar{x}$ & 4.4 & 16.4 & 11.97 & 6.7 \\
$\mathrm{~S}_{n-1}$ & 1.457 & 1.411 & 0.202 & 2.177 \\
$\operatorname{Min}$ & 1.7 & 12.4 & 11.42 & 2.5 \\
$\operatorname{Max}$ & 8.8 & 20.3 & 12.55 & 13.2 \\
\hline
\end{tabular}




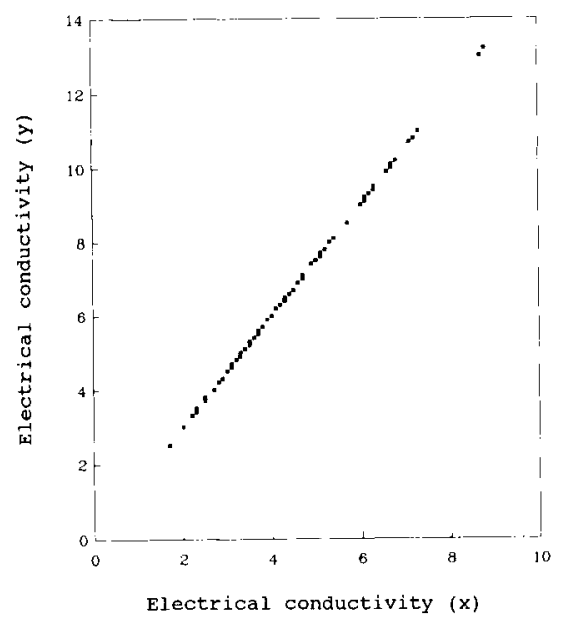

Fig 1. Graph of the relation between the electrical conductivities $\left(10^{-4} \mathrm{~S} \mathrm{~cm}^{-1}\right)$ of honey solutions in humid matter $(x)$ and dry matter $(y)$.

\section{Effect of moisture content}

The moisture content of the samples in this study varied between 12.4 and $20.3 \%$ ( mean $\left.=16.4, S_{n-1}=1.41\right)$; the second value is $63.7 \%$ higher than the first. The effect of this on the electrical conductivity is much less noticeable; to prepare $50 \mathrm{ml}$ of honey solution containing $20 \%$ dry matter $11.42 \mathrm{~g}$ is required for the honey containing $12.4 \%$ moisture, and $12.55 \mathrm{~g}$ for that containing $20.3 \%$. In this case, the second value is only $9.9 \%$ higher (mean $=11.97 \mathrm{~g}$, $S_{n-1}=0.2024$ (table I).

This in itself does not justify the excellent correlation, since a $9.9 \%$ variation in the amount weighed would have some effect on the electrical conductivity.

\section{Effect of concentration}

The relation between the electrical conductivity and percentage dry matter for 3 honeys with different electrical conductivity values (low, medium and high), obeys a second order polynomial (table II). At $\approx$ $20 \%$ dry matter, due to the increase in viscosity, there is a diminution of the ionic mobility and the curve becomes asymptotic (fig 2). Consequently, the effect of the amount weighed according to the moisture content of the sample has less influence on the electrical conductivity value.

The results of comparing the electrical conductivities of 3 solutions prepared by dissolving $11.50,12.00$ and $12.50 \mathrm{~g}$ of 10 honeys with different electrical conductivities and making them up to $50 \mathrm{ml}$ (table III) show the influence of the 2 effects discussed. The maximum variation is $\pm 0.2 \mathrm{x}$

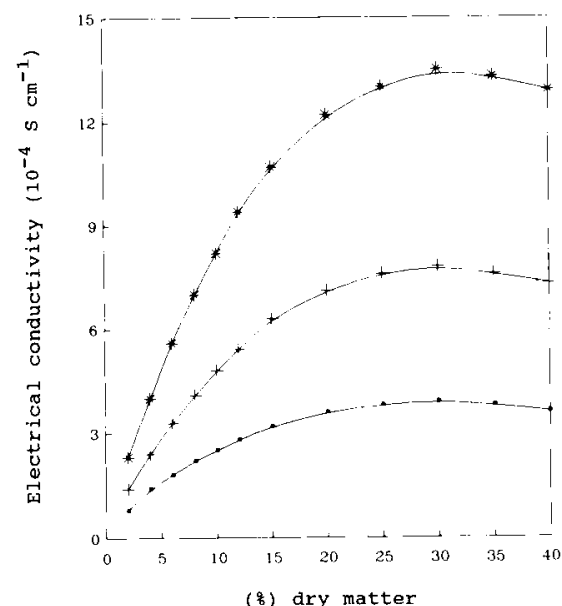

Fig 2. Graph of the relation between $\%$ of dry matter and electrical conductivity $\left(10^{-4} \mathrm{~S} \mathrm{~cm}^{-1}\right)$ in 3 honeys of low, medium and high electrical conductivity values. 
Table II. Relation between the electrical conductivity $\left(10^{-4} \mathrm{~S} \mathrm{~cm}^{-1}\right)$ and concentration of 3 honey solutions (\%) of dry matter. Values in parentheses are theoretical values from the equation $y=a+b x+c x^{2}$.
\% Dry matter

$(x)$
Electrical conductivites of the honeys (y):

\begin{tabular}{rccc}
\hline & & & \\
2 & $0.8(0.9)$ & $1.4(1.6)$ & $2.3(2.6)$ \\
4 & $1.4(1.4)$ & $2.4(2.5)$ & $4.0(4.1)$ \\
6 & $1.8(1.8)$ & $3.3(3.3)$ & $5.6(5.5)$ \\
8 & $2.2(2.1)$ & $4.1(4.0)$ & $7.0(6.8)$ \\
10 & $2.4(2.4)$ & $4.8(4.7)$ & $8.2(8.0)$ \\
12 & $2.8(2.7)$ & $5.4(5.3)$ & $9.4(9.1)$ \\
15 & $3.2(3.1)$ & $6.3(6.1)$ & $10.7(10.5)$ \\
20 & $3.6(3.6)$ & $7.1(7.1)$ & $12.2(12.3)$ \\
25 & $3.8(3.9)$ & $7.6(7.7)$ & $13.0(13.3)$ \\
30 & $3.9(4.0)$ & $7.8(7.9)$ & $13.5(13.8)$ \\
35 & $3.8(3.8)$ & $7.5(7.7)$ & $13.3(13.5)$ \\
40 & $3.6(3.5)$ & $7.3(7.1)$ & $12.9(12.5)$ \\
& & & \\
$r$ & 0.995 & 0.996 & 0.996 \\
$a$ & 0.485 & 0.631 & 1.028 \\
$b$ & 0.236 & 0.489 & 0.835 \\
$c$ & -0.004 & -0.008 & -0.014 \\
& & & \\
\hline
\end{tabular}

$10^{-4} \mathrm{~S} \mathrm{~cm}^{-1}$ for the value of electrical conductivity obtained for $16.7 \%$ dry matter.

The maximum permissible moisture content according to the Codex Alimentarius Commission (1969) is $20 \%$ except for the honey of Calluna, in which up to $23 \%$ is permitted. White, in McGregor (1979), indicates that moisture content may vary between $13-25 \%$. Of the 91 samples that Huidobro and Simal analysed (1984), 10 honeys exceeded $23 \%$ moisture content and the maximum value obtained was $24.3 \%$.

The electrical conductivities of " $x$ " and " $y$ " solutions of 10 immature honeys with moisture contents $>20 \%$ were measured (table IV). The results do not show statistically significant variation from the values predicted using $y=1.50 x$ since $t_{\text {experimental }}$ $<t_{\text {theoretical. }}$

Honeys with moisture contents ranging from $12.4-20.3 \%$ were supercharged until they contained $25 \%$ moisture (White; in McGregor, 1979; Huidobro and Simal, 1984) and the electrical conductivities were measured for " $x$ " and " $y$ " solutions. The results (table $V$ ) do not show statistically significant differences between the values of $y=1.50 x$ and the experimental " $y$ "values.

From the above it follows that the electrical conductivity of honey solution containing $20 \%$ dry matter can be estimated by measuring the electrical conductivity of a solution of $10.00 \mathrm{~g}$ of honey in $75 \mathrm{ml}$ of water (White, 1969; in AOAC 31.118, 1984) and multiplying it by 1.50 . In this manner, electrical conductivity, $\mathrm{pH}$ and acidity type can be determined without prior knowledge of the moisture content of the honey.

Table III. Variation in electrical conductivity $\left(10^{-4} \mathrm{~S} \mathrm{~cm}^{-1}\right)$ with the amount of honey required $(\mathrm{g})$ to prepare $50 \mathrm{ml}$ of solution with $20 \%$ dry matter, over the range of moisture contents of the honeys analysed from the Basque Country (Spain).

\begin{tabular}{rrrr}
$\begin{array}{c}\text { Amount weighed } \\
\text { No of test }\end{array}$ & \multicolumn{3}{c}{ Electrical conductivity } \\
& $11.50 \mathrm{~g}$ & $12.00 \mathrm{~g}$ & $12.50 \mathrm{~g}$ \\
\hline 1 & 2.4 & 2.4 & 2.4 \\
2 & 3.9 & 4.0 & 4.0 \\
3 & 5.2 & 5.3 & 5.4 \\
4 & 5.6 & 5.7 & 5.8 \\
5 & 6.4 & 6.5 & 6.6 \\
6 & 7.4 & 7.6 & 7.8 \\
7 & 8.4 & 8.5 & 8.6 \\
8 & 9.5 & 9.6 & 9.7 \\
9 & 10.4 & 10.5 & 10.6 \\
10 & 11.5 & 11.6 & 11.7 \\
\hline
\end{tabular}


Table IV. Electrical conductivity $\left(10^{-4} \mathrm{~S} \mathrm{~cm}^{-1}\right)$ of " $x$ " and " $y$ " solutions of immature honeys with moisture content $>20 \%$.

\begin{tabular}{|c|c|c|c|c|}
\hline \multirow[t]{2}{*}{ No } & \multirow{2}{*}{$\begin{array}{c}\text { Moisture } \\
\text { content (\%) }\end{array}$} & \multicolumn{3}{|c|}{ Electrical conductivity } \\
\hline & & Solution " $x$ " $(x)$ & Predicted values $(y=1.50 x)$ & Solution " $y$ " $(y)$ \\
\hline 1 & 20.7 & 4.5 & (6.8) & 6.6 \\
\hline 2 & 20.7 & 7.6 & (11.4) & 11.4 \\
\hline 3 & 20.9 & 4.8 & $(7.2)$ & 7.3 \\
\hline 4 & 20.9 & 6.9 & $(10.4)$ & 10.4 \\
\hline 5 & 21.0 & 5.0 & $(7.5)$ & 7.4 \\
\hline 6 & 22.3 & 6.5 & (9.8) & 9.8 \\
\hline 7 & 22.4 & 5.5 & (8.3) & 8.0 \\
\hline 8 & 23.0 & 3.8 & (5.7) & 5.5 \\
\hline 9 & 23.8 & 5.2 & (7.8) & 7.6 \\
\hline 10 & 24.3 & 6.1 & (9.2) & 9.1 \\
\hline $\bar{x}$ & & & (8.4) & 8.3 \\
\hline$s_{n-1}$ & & & $(1.77)$ & 1.83 \\
\hline
\end{tabular}

At the $95 \%$ probability level: $t_{\text {experimental }}=0,125 ; t_{\text {théoretical }}=2.101 ; t_{\text {experimental }}<t_{\text {theoretical }}$

Table V. Electrical conductivity $\left(10^{-4} \mathrm{~S} \mathrm{~cm}^{-1}\right)$ of " $x$ " and " $y$ " solutions of honeys supercharged up to $25 \%$ moisture content.

\begin{tabular}{|c|c|c|c|c|c|}
\hline \multirow[b]{2}{*}{ No } & \multicolumn{2}{|c|}{ Moisture (\%) } & \multicolumn{3}{|c|}{ Electrical conductivity } \\
\hline & Initial & Final & Solution " $x$ " $(x)$ & Predicted values $(y=1.50 x)$ & Solution " $\mathrm{y}$ " (y) \\
\hline 1 & 12.4 & 25 & 3.4 & $(5.1)$ & 5.3 \\
\hline 2 & 13.0 & 25 & 7.3 & $(11.0)$ & 11.0 \\
\hline 3 & 14.0 & 25 & 5.3 & $(8.0)$ & 8.1 \\
\hline 4 & 15.0 & 25 & 2.5 & (3.8) & 3.8 \\
\hline 5 & 16.0 & 25 & 4.0 & $(6.0)$ & 6.0 \\
\hline 6 & 17.0 & 25 & 7.0 & $(10.5)$ & 10.8 \\
\hline 7 & 18.0 & 25 & 6.3 & $(9.5)$ & 9.4 \\
\hline 8 & 19.0 & 25 & 5.0 & (7.5) & 7.8 \\
\hline 9 & 20.3 & 25 & 6.1 & (9.2) & 9.1 \\
\hline $\bar{x}$ & & & & $(7.8)$ & 7.9 \\
\hline$\widehat{S}_{n-1}$ & & & & $(2.48)$ & 2.47 \\
\hline
\end{tabular}

At the $95 \%$ probability level: $t_{\text {experimental }}=0.090 ; t_{\text {theoretical }}=2.1201 ; t_{\text {experimental }}<t_{\text {theoretical }}$. 


\section{ACKNOWLEDGMENTS}

The authors wish to thank the Departamento de Educación, Universidades e Investigación of the Basque Government for the grant awarded to MT Sancho Ortiz; JC Garcia Monteagudo, J Minones Trillo and JM Lopez Fonseca of the Departamento de Química Física de la Facultad de Farmacia for their disinterested help; and the Asociaciones de Apicultores del País Vasco for providing the samples that made this work possible.

Résumé - Corrélation entre la conductibilité électrique du miel et la teneur en matière humide et en matière sèche. Les mesures de la conductibilité électrique du miel servent à donner des informations sur son origine et à détecter si des abeilles ont été artificiellement nourries au sucre. On a recherché une éventuelle relation entre 2 méthodes différentes de mesure de la conductibilité électrique : dans une solution de $10 \mathrm{~g}$ de miel dans $75 \mathrm{ml}$ d'eau, utilisée pour déterminer le $\mathrm{pH}$ et le type d'acidité (White, 1962; AOAC, 1984) et dans une solution à $20 \%$ de matière sèche (Vorwohl, 1964a, b). La comparaison visait à simplifier les procédures en faisant les mesures sur une même solution. Les mesures ont porté sur 115 miels.

II existe une relation linéaire représentée par $y=1,50 \times(r=0,9998)$ (tableau I, fig 1). Cette forte corrélation est surprenante. Elle s'explique si l'on considère les effets communs des 2 propriétés : effet moindre de la teneur en eau parce que les différences dans les quantités pesées ne sont pas aussi grandes que celles attendues (tableau I) et effet de la concentration, qui obéit à une répartition polynomiale de deuxième ordre, puisque la courbe devient asymptotique à $20 \%$ de matière sèche environ (tableau II et fig 2). Le tableau III montre l'influence des 2 effets. La variation maximale de la conductibilité électrique n'est pas significative. La corrélation de la teneur en eau dans un large domaine de valeurs a été comparée en mesurant 10 miels ayant une teneur en eau supérieure à $20 \%$ (tableau IV) et 9 miels surchargés en eau (jusqu'à $25 \%$ ) (tableau V).

II ressort des résultats que la conductibilité électrique d'une solution de miel à $20 \%$ de matière sèche peut être estimée en mesurant la conductibilité électrique d'une solution de $10 \mathrm{~g}$ de miel dans $75 \mathrm{ml}$ d'eau et en multipliant la valeur par 1,50. Ainsi la conductibilité électrique, le $\mathrm{pH}$ et le type d'acidité peuvent être déterminés sans connaissance préalable de teneur en eau.

miel / conductibilité électrique / teneur en eau

Zusammenfassung - Korrelation der elektrischen Leitfähigkeit des Honigs in Flüssig- und Trockenzustand. Messungen der elektrischen Leitfähigkeit von Honigen können eine Vorstellung von seiner Herkunft geben und zur Feststellung beitragen, ob die Bienen künstlich mit Zucker gefüttert worden sind.

Es wurde nach möglichen Beziehungen zwischen zwei verschiedenen Meßverfahren der elektrischen Leitfähigkeit gesucht: Messung in einer Honiglösung von $10.00 \mathrm{~g}$ gelöst in $75 \mathrm{ml}$ Wasser, wie sie zur Bestimmung des $\mathrm{pH}$ und des Säuregrades benutzt wird (White 1962, und in dem AOAC 31.168 , 1984), und Messung in einer Lösung von 20\% Trockensubstanz (Vorwohl 1964a, b). Die Messungen, vorgenommen zur Vereinfachung des Verfahrens durch Bestimmung aller Werte in einer einzigen Lösung, wurden an $115 \mathrm{Ho}$ nigen durchgeführt. Es ergab sich eine lineare Beziehung ausgedrückt durch $y=$ $1.50 \times(r=0.9998)$ (tab I und fig 1). 
Diese hohe Korrelation ist überraschend. Als Erklärung kann das Zusammenwirken von zwei Eigenschaften angenommen werden: Ein geringer Effekt des Wassergehalts, weil die Unterschiede in den gewogenen Mengen nicht so gro $B$ sind als erwartet (tab I), und ein Effekt der Konzentration, der einer Polynomiallverteilung zweiter Ordnung gehorcht, indem die Kurve etwa bei $20 \%$ Trockensubstanz asymptotisch wird (tab II und fig 2). In tab III wird der Einfluß der beiden Effekte dargestellt. Die maximale Variation der elektrischen Leitfähigkeit ist nicht signifikant.

Die Korrelation des Wassergehalts über einen weiten Bereich wurde verglichen durch Messungen von 10 Honigen mit einem Wassergehalt über $20 \%$ (tab IV), und durch Messungen von 9 mit Wasser (bis $25 \%$ ) überladenen Honigen (tab V).

Aus obigen Ergebnissen geht hervor, daß die elektrische Leitfähigkeit einer Honiglösung mit $20 \%$ Trockensubstanz durch Messung der elektrischen Leitfähigkeit einer Lösung von $10.00 \mathrm{~g}$ Honig in $75 \mathrm{ml}$ Wasser (AOAC 31.168, 1984) und Multiplikation des Wertes mit 1.50 geschätzt werden kann. Auf diese Weise können elektrische Leitfähigkeit, $\mathrm{pH}$ und Aziditätstyp ohne vorherige Kenntnis des Wassergehalts des Honigs bestimmt werden.

\section{Honig / electrische Leitfähigkeit / Was- sergehalt}

\section{REFERENCES}

Association of Official Analytical Chemists (1984) Official Methods of Analysis (31.168). Arlington, VA, 14th ed oletin Oficial del Estado (1986) Decree of the 18th of June: Norma sobre la Miel. Imprenta Nacional del Boletín Oficial del Estado, Madrid

Codex Alimentarius Commission (1969) Recommended European Standard for Honey: CAC/ RS-12-1969. Jt FAONHO Food Stand Program, Rome; reprinted in Bee World (1970) 51 (2), 79-91

Crane E (1975) Honey: A Comprehensive Survey. Heinemann, London

Huidobro JF, Simal J (1984) Mieles de Galicia. El Campo. Bol Inf Agra (Banco de Bilbao) 93. 86-94

Kaart S (1961) Electrical methods for determining honey quality. Materials of the 5 th scientific session of the Tartu branch of the Estonian Society for Horticulture and Apiculture. Hortic Apic 89-92 (in Estonian)

Stitz J, Szigvart B (1931) Die elektrische Leitfähigkeit des Honigs. $Z$ Unters Lebensmittel 63 (2), 211-214

Vorwohl G (1964a) Die Messung der elektrischen Leitfähigkeit des Honigs und die Verwendung der Meßwerte zur Sortendiagnose und zum Nachweis von Verfälschungen mit Zuckerfütterungs-Honig. Z Bienenforsch 7 , 37-47

Vorwohl G (1964b) Die Bezlehungen zwischen der elektrischen Leitfähigkeit der Honige und ihrer trachtmäßigen Herkunft. Ann Abeille 7 (4), 301-308

White JW Jr (1962) Determination of acidity, nitrogen and ash in honey. $J$ Assoc Off Anal Chem 45 (3), 548-551

White JW Jr (1969) Moisture in honey: review of chemical and physical methods. J Assoc Off Anal Chem 52 (4), 729-737

White JW Jr (1979) Composición y propriedades de la miel. In: La Apicultura en los Estados Unidos (McGregor SE, ed) Limusa, Mexico, 57-66 